\title{
Benign Tongue Neoplasm
}

National Cancer Institute

\section{Source}

National Cancer Institute. Benign Tongue Neoplasm. NCI Thesaurus. Code C3592.

A non-metastasizing neoplasm that arises from the tongue. 